\title{
Potentials of Microalgae Biodiesel Production in Nigeria
}

\author{
Ogbonna, I. O. ${ }^{1,2}$, Moheimani, N. R. ${ }^{3}$ and Ogbonna, J. ..$^{1}$ \\ ${ }^{1}$ Department of Microbiology, University of Nigeria, Nsukka, Nigeria \\ ${ }^{2}$ Department of Biological Sciences, Federal University of Agriculture, Markurdi, Nigeria \\ ${ }^{3}$ Algal R\&D Centre, School of Veterinary and Life Sciences, Murdoch University, Western Australia
}

\begin{abstract}
Bio-energies are renewable, sustainable and environmentally-friendly. Although Nigeria has a lot of various biomass materials, production of bio-fuels in Nigeria is faced with a lot of challenges. It has been argued that large scale production of bio-energies from food crops as replacement or supplements to fossil fuels cannot be realistically achieved because of possible negative effects on food security. There is high potential for largescale production of biodiesel from microalgae in Nigeria. Establishment of biodiesel production industries in Nigeria will have positive effects on socio-economic development of the country. It has been estimated that Nigeria currently needs about 27 thousand barrels of biodiesel per day to be able to replace the entire consumed fossil diesel with B20 blends. There is therefore an urgent need to isolate and develop productive strains that are adapted to non-arable lands in Nigeria, develop appropriate photo bioreactors and culture systems for large scale production of microalgae biodiesel, and develop bioenergy friendly policies and incentives to encourage bio-energy production in Nigeria.
\end{abstract}

Keywords: bio-energy; climatic conditions; fossil fuel; microalgae; production economics

Correspondence: innocentia09@yahoo.com

\section{Introduction}

The world is currently facing a perceptible problem of oil crisis with the current high rate of consumption of fossil fuel. Fossil fuels are non-renewable and its consumption has been projected to rise by about $60 \%$ in the next 25 years (Rittmann, 2008). This, together with significant depletion in resources over the next few decades, can result in further economical constraints (Veziroglu and Sahin, 2008). Although Nigerian energy resources include crude oil, natural gas, coal and renewable energy from biomass, hydro, solar and wind, it has been reported that only crude oil and natural gas are well developed (Abiodun, 2007). Nigeria has petroleum reserves and petroleum provides $95 \%$ of foreign trade earnings and about $80 \%$ of budget revenues (Bala-Gbogbo, 2010). Current estimated oil reserve in Nigeria is 37 billion barrels (sixth largest petroleum exporter) with daily production capacity of 2.5 million barrels of crude oil. This implies that at the current rate of utilization, the oil will be depleted by 2053 (OPEC Oil Reserve Data, 2012). Currently, Nigeria imports about $80 \%$ of required refined petroleum and has encountered increasing cost over the years (Oniya and Bamgboye, 2012). The recent partial removal of oil subsidy by the Federal Government of Nigeria places the majority of the population at risk of financial insecurity.

The biomass resources comprise those resources which are generated from agriculture, wood industries, as well as agroprocessing and municipal wastes (Highina et al., 2011). Nigerian non-fossil fuel energy sector is dominated by biomass. However, due to processing cost and environmental pollutions, the produced biomass is not yet used for transportation in Nigeria (Highina et al., 2011). Biomass contributes about $78 \%$ of Nigerians' primary energy supply (Agbro and Ogie, 2012). Biomass productivity of tropical and sub-tropical countries is five times higher than non-tropical countries because of availability of freshwater and abundant supply of affordable land and labour (Sielhorst et al., 2008). Currently, Nigeria has no commercial biodiesel plant except for a few smallundocumented production facilities (Idusuyi et al., 2012). Nigerian government indicated commitment to biofuel production from local 
feedstock with emphasis on bio-ethanol and biodiesel with projected annual local marketability of 5.04 billion and 900 million litres, respectively (Galadima et al., 2011). However, biofuel production in Nigeria is challenged by: (i) lack of infrastructure (ii) lack of technical skills (iii) fears of competition with food, and (iv) inadequate fund provision (Samuel and Adekomaya, 2012). Oniemola and Sanusi (2009) also concluded that there are still lack of enabling legislation in the Nigerian energy sector, little technical information on bio-fuel, logistics bottlenecks, none encouragement of research and development, no multi-sectoral coordination and support, and no appropriate fiscal and economic incentives. One potential source of bio-energy production and $\mathrm{CO}_{2}$ bioremediation is microalgae (Moheimani et al., 2012; Borowitzka and Moheimani, 2013). This review attempts to assess potential use of microalgae as a source of bio-energy in Nigeria.

Biodiesel feedstocks in Nigeria
Oil crops (distribution and productivity): Major biofuel crops for producing bio-ethanol and bio-diesel in Nigeria are summarized in Table 1. Nigeria is the world highest producer of cassava. The average yield of palm oil is 1,300,000 MT (Abila, 2011). Palm oil can have productivities up to 636 gallons/acre/year (Chisti, 2007). In the SubSaharan Africa, Nigeria is the highest producer of sorghum. Their production accounts for about $70 \%$ of the total production in the region (Galadima et al., 2011). In the year 2007/2008 an estimate of 100, 000 tons of sugar cane was produced compared to 80,000 tons in 2006/2007 and Nigeria was the second largest producer in Africa (Agboire et al., 2002). Soybeans have relatively low oil productivity of 61.3-76.61L/ha/year (Pimentel and Patzek, 2005). In the Eastern Nigeria, Jatropha plant is used for marking land boundaries between households and villages. Few research plantations were recently established in the Northern Nigeria as pilot studies for checking desertification (Galadima et al., 2011). With the current biofuels plan, some Northern States were selected for large-scale Jatropha production (Galadima et al., 2011).

Table 1. Some of the biofuel crops in Nigeria.

\begin{tabular}{|c|c|c|c|c|c|c|}
\hline Crop & $\begin{array}{l}2007 \\
\text { Average } \\
\text { Yield (MT) }\end{array}$ & $\begin{array}{l}\text { Biofuel } \\
\text { type } \\
\text { derivation }\end{array}$ & $\begin{array}{l}\text { Derivable } \\
\text { biofuel } \\
\text { yield } \\
\text { (L/Ha) }\end{array}$ & $\begin{array}{l}\text { Nigeria's } \\
\text { production } \\
\text { rank } \\
\text { (global) }\end{array}$ & $\begin{array}{l}\text { Fruit to } \\
\text { oil } \\
\text { ratio } \\
(\%)\end{array}$ & $\begin{array}{l}\text { Litres of } \\
\text { oil/hectare }\end{array}$ \\
\hline Sesame & 100,000 & Biodiesel & 696 & $7^{\text {th }}$ & & \\
\hline Palm oil & $1,300,000$ & Biodiesel & 5,950 & $3^{\text {rd }}$ & $20-26$ & 5950 \\
\hline Palm kernel & $1,275,000$ & Biodiesel & 5,950 & $3^{\text {rd }}$ & $36-40$ & \\
\hline Groundnut & $3,835,600$ & Biodiesel & 1,095 & $3^{\text {rd }}$ & $42-44$ & 1059 \\
\hline Soy bean & 604,000 & Biodiesel & 446 & $11^{\text {th }}$ & & \\
\hline Coconut & 225,500 & Bio-ethanol & 2.689 & $17^{\text {th }}$ & $60-62$ & 2689 \\
\hline Sugar cane & $1,506,000$ & Bio-ethanol & 6,000 & $51^{\text {st }}$ & & \\
\hline Cotton seed & 212,000 & Biodiesel & 325 & $16^{\text {th }}$ & $13-15$ & 325 \\
\hline Cassava & $34,410,000$ & Bio-ethanol & 4,000 & $1^{\text {st }}$ & & \\
\hline Sweet corn & $6,724,000$ & Bio-ethanol & 172 & $10^{\text {th }}$ & & \\
\hline
\end{tabular}

Adapted from Abila (2011) and www.journeytoforever.org/Biodiesel yield. hmail.

NB: None of these crops is currently cultivated for biofuel in Nigeria.

Microalgae: The global craving for bioenergy as replacement for petroleum fuel on the ground of sustainability, renewability and carbon neutral alternative cannot be realistically achieved with the use of oil crops (Chisti, 2007). Oil-rich microalgae have been reported by many to be a promising alternative source of lipids for biofuel production (Chisti, 2007; Li et al., 2008; Song et al., 2008; Zhang et al., 2010; de Boer et al 2012). Microalgae have the following advantages over other crops: (1) In general, microalgae have higher growth rates resulting in smaller land usage; 15-300 times more oil is produced with microalgae than conventional crops on a perarea basis (Li et al., 2010,Schenk et al., 2008). (2) They have high lipid content - more than $50 \%$ of cell dry weight (Hu et al., 2008). (3) They can grow on saline and hyper-saline water, and thus there is less dependency on freshwater (Sing et al., 2013). (4) They have high carbon sequestration rate (J orquera et al., 
2010; Moheimani et al., 2012). Furthermore, algal biomass production systems can easily be adapted to various levels of biotechnological skills (Vonshak, 1990).

Microalgal lipid yields are much higher than those obtained for terrestrial plants as compared in the review of Chisti (2007). In real sense, there are many reports showing that oil contents of many species of microalgae are above $30 \%$. For instance, Ogbonna and Ogbonna (2015) obtained lipid content and productivity of $67.23 \%$ and $165.5 \pm 3.36 \mathrm{mg} \mathrm{L}^{-1}$ $\mathrm{d}^{-1}$, respectively for a Chlorella sp. Lipid productivity of Chlorella vulgaris ESP-31 of 144 $\mathrm{mg} \mathrm{L}^{-1} \mathrm{~d}^{-1}$ with lipid content of $53 \%$ was recorded (Yeh and Chang, 2012). Feng et al. (2011) reported highest percentage lipid and productivity of $54.5 \%$ and $22.3 \mathrm{mg} \mathrm{L}^{-1} \mathrm{~d}^{-1}$ for Chlorella zofingiesis. Li et al. (2011) obtained much higher lipid productivity $\left(0.29 \mathrm{~g} \mathrm{~L}^{-1} \mathrm{~d}^{-1}\right)$ in optimized growth of Chlorella minutissima UTEX2341. Liu et al. (2011) reported ranges of lipid content (in percentage, 18.67 \pm 2.94 $52.08 \pm 2.37$ ) and lipid productivity (in $\mathrm{mg} \mathrm{L}^{-1}$ $\mathrm{d}^{-1}, 13.74 \pm 2.94$ - 194.27 \pm 1.56$)$ for Chlorella sp. In addition, Mata et al. (2010) reported maximum lipid content and productivity for different strains of Chlorella sp. as $63.0 \%$, and $121.4 \mathrm{mg} \mathrm{L}^{-1} \mathrm{~d}^{-1}$, respectively. Moheimani (2013) reported lipid productivity of $99 \pm 17.2$ mg lipid $\mathrm{L}^{-1}$ day $^{-1}$ for a Chlorella sp. Lipid content (\% biomass), lipid productivity ( $\mathrm{mg} \mathrm{L}^{-1}$ day $^{-1}$ ) obtained by Khan et al. (2009) for Chlorococcum sp. UMACC 112 were 19.3 and 53.7, respectively whereas Mata et al. 92010) reported lipid contents of $25.0-75.0 \%$ for Botryococcus braunii. Algal cultivation in Nigeria and other African Countries is presented in Table 2. Other algal isolation and identification in Nigeria abound (Kadiri, 1999; Nwankwo, 1996; Opute, 1991). Adoki (2008) reported the isolation of Amphiprora sp, Cyclotella striata, Coscinodiscus radiata, Dictylum brighwelli, Diatoma liemale, Melosiru granulata, Navicula cupsidata, Navicula minima, Pinnularia gibba, Nitzschia closterium, and Naviculabactillum; seven blue green algae namely Anacystis georginosa, Anabaena flosaguae, Oscillatoria sancta, Oscillatoria chadybaca, Phormidium uncinactum, Pleurosyna donyatum and Oscllatoria sp. and four green algae namely, Schiothrix pulvinata, Scenedesmus quadricauda, and Chlorella sp. These organisms were investigated for petroleum hydrocarbon utilization (Adoki, 2008). Thus, although there are many works on isolation of microalgae in Nigeria, there are very scarce information on their oil contents and productivities (Ogbonna and Ogbonna, 2015), and thus their potentials for biodiesel production.

There are only very scanty reports on microalgae cultivation in Nigeria (Table 2). However, in Nigerian natural water environments, many of these microalgae species grow abundantly in gutters, ditches, ponds, puddles, rivers, seas, ocean and many water bodies, especially during the rainy season. These organisms are observed to grow naturally in both humid and arid environments of Nigeria. Some of these algae grow and form bloom with consequent effects on the water ecosystem. Some eventually die but most survive and resume growth when favourable conditions returns.

Table 2: Algal cultivation in Nigeria and other African Countries

\begin{tabular}{|c|c|c|c|c|c|}
\hline $\begin{array}{l}\mathrm{S} / \mathrm{N} \\
0\end{array}$ & Microalgae & $\begin{array}{l}\text { Size of } \\
\text { production }\end{array}$ & $\begin{array}{l}\text { Type of } \\
\text { reactor }\end{array}$ & $\begin{array}{l}\text { Reason for } \\
\text { cultivation }\end{array}$ & Refs. \\
\hline 1 & Chlorella sp. & $\begin{array}{l}\text { Laboratory } \\
\text { scale }\end{array}$ & $\begin{array}{l}\text { 500ml } \\
\text { Erlenmeyer } \\
\text { flasks }\end{array}$ & Biofuel & Agwa et al. (2012) \\
\hline 2 & Chlorella sp. & $\begin{array}{l}\text { Laboratory } \\
\text { scale }\end{array}$ & $\begin{array}{l}\text { continuously } \\
\text { stirred } \\
\text { reactor }\end{array}$ & Biofuel & J egede, (2012) \\
\hline 3 & Chlorella sp. & $\begin{array}{l}\text { Laboratory } \\
\text { scale }\end{array}$ & $\begin{array}{l}100 \mathrm{ml}- \\
\text { conical } \\
\text { flasks }\end{array}$ & Food related & $\begin{array}{l}\text { Anaga and Abu } \\
\text { (1996); } \text { Adoki } \\
\text { (2008) }\end{array}$ \\
\hline 4 & Spirulina sp & $\begin{array}{l}\text { Laboratory } \\
\text { scale }\end{array}$ & $\begin{array}{l}100 \mathrm{ml}- \\
\text { conical } \\
\text { flasks }\end{array}$ & Food related & $\begin{array}{l}\text { Anaga and Abu, } \\
\text { 1996; Habib et al., } \\
\text { 2008; Abu et al., } \\
\text { 2007; Ogbonda et } \\
\text { al., } 2007\end{array}$ \\
\hline
\end{tabular}




\begin{tabular}{|c|c|c|c|c|c|}
\hline 5 & $\begin{array}{l}\text { Oocystis IA1, Chlorella } \\
\text { IA7, Chlorococcum KA9 } \\
\text { and Botyrococcus YA5 }\end{array}$ & $\begin{array}{l}\text { Laboratory } \\
\text { scale }\end{array}$ & $\begin{array}{l}\text { 2litre } \\
\text { Transparent } \\
\text { Teflon } \\
\text { plastic } \\
\text { bottles }\end{array}$ & Biodiesel & $\begin{array}{l}\text { Ogbonna, (2014); } \\
\text { Ogbonna and } \\
\text { Ogbonna, } 2015\end{array}$ \\
\hline 6 & Chlorella vulgaris & $\begin{array}{l}\text { Laboratory } \\
\text { scale }\end{array}$ & $\begin{array}{l}1 \text { litre } \\
\text { polycarbona } \\
\text { te bottles }\end{array}$ & $\begin{array}{l}\text { Lipid } \\
\text { composition }\end{array}$ & Chia et al (2013a) \\
\hline 7 & Chlorella vulgaris & $\begin{array}{l}\text { Laboratory } \\
\text { scale }\end{array}$ & $\begin{array}{l}1 \text { litre } \\
\text { polycarbona } \\
\text { te bottles }\end{array}$ & $\begin{array}{l}\text { Lipid } \\
\text { composition }\end{array}$ & Chia et al. (2013b) \\
\hline
\end{tabular}

Potential locations for mass cultivation of microalgae in Nigeria

Nigeria is a tropical country in the West African sub-region lying in the latitude $4-14^{\circ}$ $\mathrm{N}$ and longitude $2-14^{\circ} \mathrm{E}$, and bordered by countries shown in Fig. 1. Given the Nigerian's environmental conditions, there is high potential for large-scale cultivation of microalgae because the solar light intensity and duration are high while temperature (20 $\sim 40^{\circ} \mathrm{C}$ ) is suitable for growth of many species of microalgae in almost all parts of the country throughout the year. Their average yearly values make almost all parts of Nigeria potentially suitable for mass cultivation of microalgae.

\section{(A)}

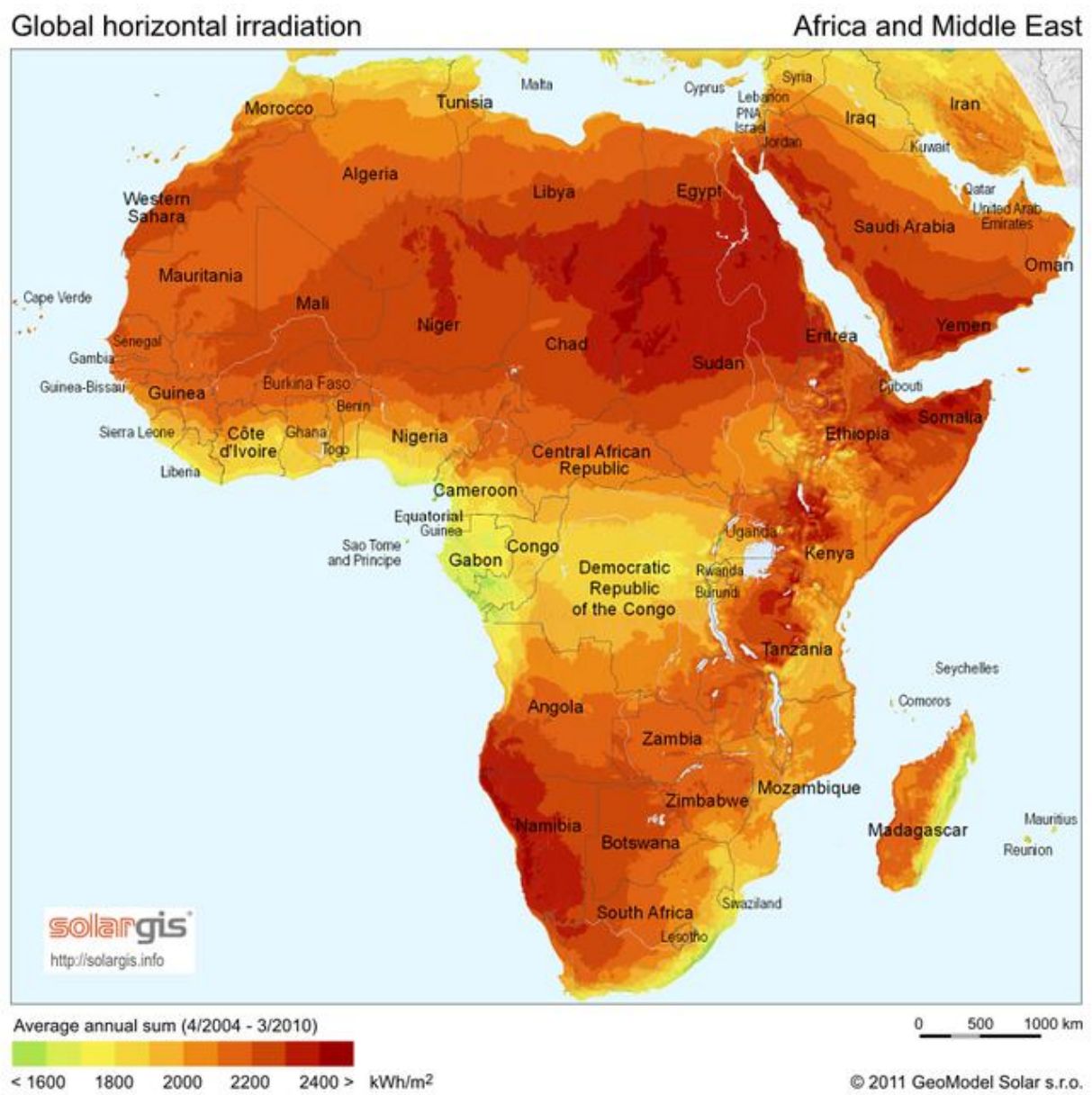




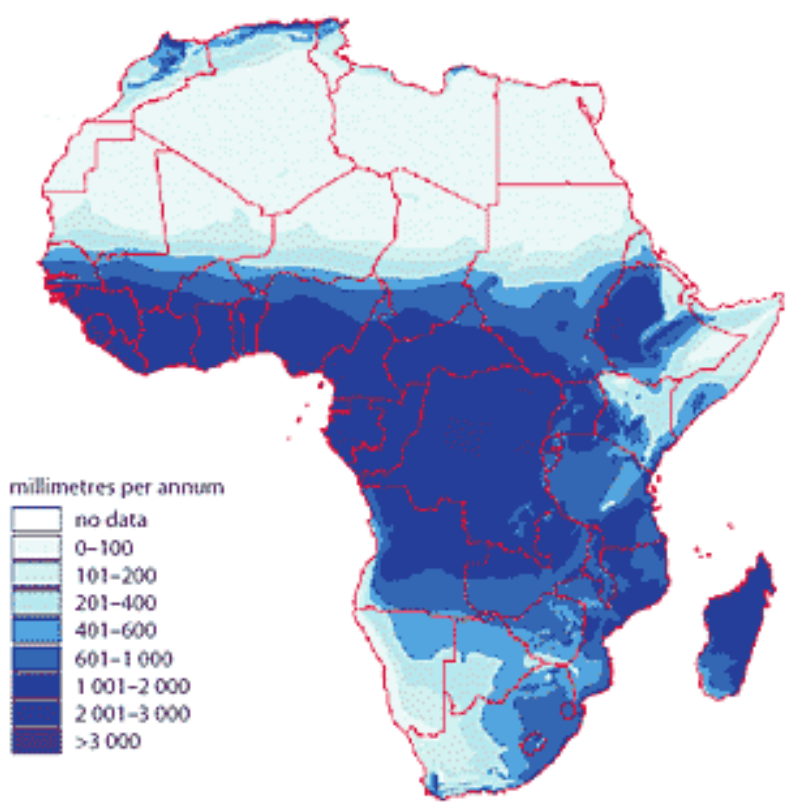

Figure 1. Climatic maps of Africa showing solar light intensity (A), and rainfall patterns (B).

\section{Sources:}

(A): http://en. wikipedia.org/wiki/Renewable energy in Africa\#mediaviewer/File:SolarGIS -Solar-map-Africa-and-Middle-East-en.png. (B): http://www.catsg.org/cheetah/07_mapcentre/7_1_entire-range/thematic-maps/annual_rainfall_Africa.gif

Environmental conditions that favour algal cultivation in Nigeria

Solar light intensity: Light is by far the most important limiting factor in growth of microalgae. Light intensity plays a significant role in the cultivation and product formation of microalgae. It relates directly to the amount of energy supplied to the photosynthetic apparatus and influences biochemical reactions in the cell (Terry et al., 1983; Curtis and Megard, 1987; Meseck et al., 2005) including the degree of lipid saturation (Thompson et al., 1990; Klyachko-Gurvich et al., 1999; Fábregas et al., 2004). Studies have shown that very high light intensity leads to photo-inhibition of microalgae growth and reduction in lipid productivity (Luo and Al-Dahlan, 2004). On the other hand, insufficient light intensity has been associated with biomass loss (Ogbonna and Tanaka, 1996; Scott et al., 2010). Yearly mean values of light intensity in Nigeria for some states: Enugu, Benin, J os, Kaduna, Owerri, and I keja from 1993 to 2003 are 2541, 2368, 1440, 2837, 2039 and $1783 \mu \mathrm{mol}$ photons. $\mathrm{m}^{-2} \cdot \mathrm{s}^{-1}$, respectively (meteorological data from different parts of Nigeria). They are all within the range of light intensity known to be optimum for growth and product formation by many strains of microalgae. The current large scale D. salina plant is based at Hutt Lago with annual average solar radiation of $18 \sim 24 \mathrm{MJ} / \mathrm{m}^{2}$. This compares with the monthly mean global radiation levels of $191.1 \sim 352.1 \mathrm{~kW} \mathrm{\textrm {m } ^ { 2 }}$ (16.5 30.4 MJ $/ \mathrm{m}^{2}$ ) reported for Owerri, Nigeria (Chidiezie et al., 2005), and the 10 year average visible radiation of 24.758 to 48.778 $\mathrm{MJ} / \mathrm{m}^{2}$ for various parts of Nigeria (Ali and Ogbonna, 2011).

Light duration (hours of sunshine): The hour of sunshine significantly affects the growth and lipid productivity of microalgae species. Sing (2010) identified three photoperiods for microalgae grown outdoors to include seasonal, diurnal and the in situ light/dark cycles caused by turbulence within the culture system. Light: dark cycles affect cell division, photosynthesis and metabolism (Sicko-Goad and Andresen, 1991; Thompson, 1999; Ugwu et al., 2005). Climatic records in most parts of Nigeria over a period of ten years (1993 through 2003) showed that the mean hours of sunshine that can support active growth of microalgae do not reach 12 hours per day (meteorological data from different parts of Nigeria). Records of the yearly mean values of hours of sunshine in Nigeria for some states including Enugu, Benin, Jos, Kaduna, Owerri, and I keja from 1993 to 2003 
respectively are 7.58, 6.11, 7.4, 7.35, 6.0 and 7.07 hours (meteorological data from different parts of Nigeria). However, the practical day length hours that fall within photosynthetically active range of light in Nigeria is always more than 12 hours. Microalgae whose optimum light period requirements are within the range of 6.0 to 14 hours per day are best suited to Nigerian conditions.

Temperature: Microalgae are known to have temperature optima for both growth and lipid production. The yearly mean values of temperature in Nigeria of some states: Enugu, Benin, Jos, Kaduna, Owerri, and Ikeja from 1993 to 2003 respectively of 27.3, 27.3, 21.8, 29.6, 27.6 and $27.5{ }^{\circ} \mathrm{C}$ (Ali and Ogbonna, 2011) fall within the range of optimum temperature reported to support the growth and lipid production by most strains of microalgae. Therefore, for the cultivation of microalgae in Nigeria, temperature may not need any adjustment as it falls within the range reported to be optimum for many species. Temperature fluctuation is also very important for algal growth and product formation. The minimum and maximum temperatures, as well as seasonal variations in temperature all affect algal growth. In many parts of Nigeria, the minimum temperature does not fall below 15 ${ }^{\circ} \mathrm{C}$ throughout the year but the maximum temperature can get as high as $40{ }^{\circ} \mathrm{C}$ depending on the season and location. Thus, microalgae can be cultivated throughout the year. In some other countries, warm weather (summer) is short and for more than 6 months in a year, the temperature is below $10^{\circ} \mathrm{C}$, making it impossible to cultivate many species of microalgae. In Nigeria, daily fluctuation in temperature is minimal.

Rainfall patterns (seasonal variations): Nigeria has rainy and dry seasons. During the rainy season, different microalgae growth is obtained in almost every corner of the country in water bodies including gutters, ditches, ponds, puddles, rivers, seas and ocean. The effects of seasonal variation in rainfall on microalgae growth and lipid production are better felt in open pond cultures. Seasonal variation influences the volume of water bodies, humidity, dryness and indirectly the metabolic activities of the algae. They also determine the quantities of dissolved matter available to the algae. Rainfall can cause a sudden deluge of water into an open pond, change the water chemistry, and allow algae to escape due to pond overflow (Knoshaug and Darzins, 2011). Another problem with open pond during the rainy season is the infestation of the algae by some herbivorous aquatic animals such as toads and their larvae. Conversely, algal blooms are observed only during the rainy season because when the water bodies dry up during the dry season, the microalgae enter into the resting stage (spores etc depending on the strain). In some cases, rain helps to replace water lost through evaporation, and thus restores the salinity of the ponds. In fact, during the dry season, water is intentionally added to ponds to replace the water lost. Thus, the influence of rain depends mainly on the quantity. Rain season can also indirectly affect algal production by shading of solar radiation by clouds. Closed photobioreactors are scarcely influenced by rainfall pattern; however, costs could be prohibitive which makes its application un-economical for most products such as biodiesel.

\section{Possible sources of carbon dioxide for algae} culture in Nigeria

Reports show that carbon dioxide has a profound effect on the growth and lipid accumulation by phototrophic microbial cells both due to its effect on medium $\mathrm{pH}$ as well as on the availability of bicarbonates used by the cells as carbon source ( $\mathrm{Hu}$ and Gao, 2003; Cheng et al., 2006; Chiu et al., 2009; Hsueh et al., 2009; Moheimani, 2013). In Nigeria, gases from oil wells are continuously burnt in many places in Niger-Delta, resulting in environmental pollution (Oghifo, 2011). Many international organizations have been demanding that Nigeria stops gas flaring (Oghifo, 2011). Okolocha (2010) reported that Nigeria flares more gas than any other country in the world. This is a major source of $\mathrm{CO}_{2}$ in Nigeria. Incidentally, many of the gas flaring stations are very close to sea. Thus, many marine algae culture systems can be located close to the gas flaring stations for efficient supply of sea water and carbon dioxide. In addition, other anthropogenic activities in Nigeria are releasing enormous amounts of $\mathrm{CO}_{2}$ to the atmosphere. For instance, Okolocha (2010) reported that 60 million Nigerians own power generators, 98 per cent of businesses own private generators, government offices as well as official and private residences of all political office holders are mostly run with generators and average annual residential expenditure in fuelling generators stand at N1.56 trillion. Carbon dioxide in flue gases can be captured by chemical absorption, cryogenic fractionation, membrane separation, and 
adsorption using molecular sieves (Herzog et al., 2000). A technology patented by GonzálezLópez et al. (2009) allows $\mathrm{CO}_{2}$ capture from flue gases and transferring it to microalgae cultures. Furthermore, many industries can supply cheap $\mathrm{CO}_{2}$ in form of flue gases. For instance, coal mining in Enugu and other industries generate smoke rich in $\mathrm{CO}_{2}$ and algal firm can be co-located to utilize the cheap $\mathrm{CO}_{2}$. There are many spring waters around the coal mines and these can provide very good sources of water for large scale algae cultures. Besides, other possible sources of carbon dioxide in Nigeria include pure carbon dioxide supplied via gas cylinders. The major problems with the use of pure $\mathrm{CO}_{2}$ are cost and low scale. A third possible source of $\mathrm{CO}_{2}$ is using $\mathrm{CO}_{2}$ from the atmosphere. However, the atmospheric carbon dioxide concentration is very low, and thus will be a limiting factor especially during the sunny hours in high density cultures. This problem can be solved by operating mixotrophic cultures by adding small amounts of cheap organic carbon source.

Bioreactors suitable for algae cultivation in Nigeria

Production of microalgae oil is faced with a number of technical constraints of which photobioreactor configuration is one (Chen et al., 2011). A number of factors determine the choice of a photobioreactor including light supply efficiency (Ogbonna et al., 1996) operational stability, costs and resource availability. Although many types of closed photobioreactors have been designed, with the current prices of biodiesel, and the large scale required to make biodiesel production profitable, it is unlikely that any closed photobioreactor can be used for commercial photoautotrophic cultivation of algae for biodiesel production. They may be good for high value compounds but not for biodiesel. Therefore, microalgae could be cultivated for dual purpose of producing biofuel and other high value materials. This method is called the co-product concept or integrated approach. In this method, after cultivation of microalgae some high value compounds are first extracted, followed by extraction of the oil, and finally the residual biomass is used as protein source for animals etc. Furthermore, many of the oleaginous species of microalgae can grow heterotrophically and the current heterotrophic bioreactors can be used for large scale biodiesel oil production (Ogbonna and Moheimani, 2015). For photoautotrophic cultures, open ponds are thus more feasible, despite the low productivity and other problems associated with open air photobioreactors.

Economics of Microalgae biofuel production in Nigeria

Many authors have argued on the feasibility of biodiesel being a practical replacement of petro diesel on the ground of cost. Even when the Nigerian climatic conditions are suitable for the production of biodiesel, there are still many technical challenges confronting biodiesel production the world over. These challenges include the following: (1) the production cost is high for both the up and down stream processing. (2) National legislation in favor of biodiesel production (Highina et al., 2011; Bugaje and Mohammed, 2008) is lacking in Nigeria. (3) Other challenges facing commercial production of biodiesel include competition between foodcrop and bio-fuel production, requirement for large land area (Chisti, 2007), economic nonfeasibility and environmental pollution (Schenk et al., 2008). Therefore, for sustainability, microalgae are the present candidates not only in Nigeria but globally. Ogbonna (2014) has argued that if properly managed, large scale production of bio-energy can be done in most African countries without negative effect on food crop production. However, de Boer et al. (2012) reported that if the target is production of biofuel from microalgae, the hydrothermal liquefaction is the way to go.

Potential effects of microalgae bio-energy production on socio-economic development of Nigeria

Investing in biofuels would promote employment (Sielhorst et al., 2008; Abila, 2011; Idusuyi et al., 2012; Oshewolo, 2012), diversify Nigeria's source of income and choose a cleaner development pathway through low carbon energy alternatives and potentially contributes to poverty reduction (Oshewolo, 2012; Abila, 2011). Nigeria has a population of about 170 million people, and a total land area of 923, $768 \mathrm{~km}^{2}$ (comprising 910, $768 \mathrm{~km}^{2}$ of land and $13000 \mathrm{~km}^{2}$ of water). Approximately $33 \%\left(300,550 \mathrm{~km}^{2}\right)$ is arable, $3.1 \%(28,235$ $\mathrm{km}^{2}$ ) is under permanent crop, $44 \%$ is under permanent pasture, $12 \%$ is under forest and woodland and $0.3 \%\left(2,820 \mathrm{~km}^{2}\right)$ is under irrigation (Abiodun, 2007; Agbro and Ogie, 2012). Some places in Nigeria are not suitable for conventional agriculture. For instance, in 
some states in the Northern Nigeria like Maiduguri, the quantity of annual rainfall is too low to support conventional agriculture and thereby leaves an expanse of land with no vegetation over a long period of time. In addition, some areas in the south are marshy and not suitable for conventional agriculture. In the South Eastern Nigeria, some marginal lands that are erosion prone can be used for algal farm. Therefore, many community scale microalgae cultures can be established in such places. They can thus produce oil-rich biomass and sell to a central processing company that extracts the oil, convert to fatty acid methyl esters (FAME) and sell to gasoline stands (Ogbonna, 2014). Some legal issues relating to biodiesel production and utilization are in place in Nigeria. Okolocha (2010) reported that NNPC introduced a biofuel policy, which envisaged the introduction of composite fuels with 10 per cent of ethanol in premium motor spirit (E10) and 20 per cent of biodiesel in petro diesel (B20). Nigerian Motor Gasoline Production and Consumption from the year 2000 through 2010 is presented in Table 5. Therefore Nigeria needed about 27 thousand barrels of biodiesel per day in the year 2011 to be able to make a B20 blend for the entire diesel used in the country.

Table 1. Nigeria Motor Gasoline Production and Consumption by Year (Thousand Barrels per Day).

\begin{tabular}{lll}
\hline Year & Production & Consumption \\
\hline 2000 & 24.26 & 117.81 \\
2001 & 60.67 & 150.81 \\
2002 & 60.83 & 154.78 \\
2003 & 24.21 & 150.27 \\
2004 & 12.45 & 149.34 \\
2005 & 40.62 & 154.87 \\
2006 & 23.21 & 149.47 \\
2007 & 6.71 & 142.07 \\
2008 & 16.31 & 163.71 \\
2009 & 8.51 & 163.80 \\
2010 & 17.48 & 135.05 \\
\hline
\end{tabular}

Source: United States Energy I nformation Administration

(http://www.indexmundi.com/energy.aspx?cou ntry=ng\&

product=gasoline $\alpha g r a p h=$ production+consump tion).

\section{Conclusion}

In conclusion, Nigeria needs biofuels and has high potential for their development. Even though microalgae based biofuel has its bottlenecks related to oil productivity, it is the best for Nigeria because of food and environmental challenges presented by the other feedstocks. Nigeria has enabling environment for large-scale microalgae cultivation but lacks the policy framework that translates to effective production and utilization of biodiesel and not mere paper work. Largescale microalgae cultivation would give job, money, and healthy lives to Nigerians. To start microalgae biodiesel production in Nigeria, we need the following: oil rich microalgae and appropriate photo-bioreactors (open system is recommended because of cost). The major issue to be addressed is that of obtaining the oil in sufficient quantities. However, with the species of microalgae already isolated which contains more than $50 \%$ oil (Ogbonna and Ogbonna, 2015), and assuming biomass productivity of $30 \mathrm{~g} / \mathrm{m}^{2} . d$ in a $10 \mathrm{~cm}$ deep open pond (Terry and Raymond, 1985; Laws et al., 1986) a plot of land $(50 \mathrm{~m} \times 100 \mathrm{~m})$ will yield $75 \mathrm{~kg}$ of oil every day. Thus, although presently we do not know of any commercial biodiesel oil production in Nigeria, we believe that establishment of large scale biodiesel oil production is both feasible and economical and will have positive effects on socio-economic development of Nigeria.

\section{References}

Abila, N. (2011). Promoting Biofuels Adoption in Nigeria: A Review of Socio-economic Drivers and Incentives. World Renewable Energy Congress 2011-Swedeen 813 May 2011, LinkÖping, Sweden 359-364.

Abiodun, O. (2007). Biofuel Opportunities and Development of renewable energies Markets in Africa: A paper presented during the biofuel market Africa 2007 conference, Cape Town, South Africa.

Abu, G.O. Ogbonda, K.H. Amingo R.E. (2007). Optimization studies of biomass production and protein biosynthesis in a Spirulina sp. isolated from an oil-polluted flame pit in the Niger Delta. Afri. J. Biotechnol. 6: 2550-2554.

Adoki, A. (2008). Response of microalgae from mud-flats to petroleum hydrocarbons in the presence of nitrogenous fertilizer effluents. Afri. J. Biotechnol. 7: 622-630.

Agboire, S. Wada, A.C. Ishaq, M.N. (2002). Evaluation and characterization of sugarcane 
germplasm accessions for their breeding values in Nigeria. The Journal of Food Technology in Africa 7: 33 - 35.

Agbro, E.B. Ogie, N.A. (2012). A comprehensive review of biomass resources and biofuel production potential in Nigeria. Res. J. Eng. Appl. Sci. 13: 149-155.

Agwa, O.K. Ibe, S.N. Abu, G.O. (2012). Biomass and lipid production of a fresh water algae Chlorella sp. using locally formulated media. Int. Res. J. Microbiol. 3: 288-295.

Ali, F. U. and Ogbonna, J. C. (2011).Suitability of Nigerian weather conditions for cultivation of microalgae. Nigerian J ournal of Biotechnology. 22: $60-65$.

Anaga, A. Abu, G.O. (1996). A laboratory scale cultivation of Chlorella sp and Spirulna sp using waste effluent from a fertilizer company in Nigeria. Bioresour. Technol. 58: 93-93.

Bala-Gbogbo, E. (2010). Nigeria's Oil Revenue Rose $46 \%$ to $\$ 59$ Billion in 2010 on Improved Security

(http://www. bloomberg.com/news/2011-0414/nigeria-s-oil-revenue-rose-46-to-59-billionin-2010-on-improved-security.html).

Borowitzka, M.A. Moheimani, N.R. (2013). "Sustainable biofuels from algae." Mitigation and Adaptation Strategies for Global Change 18: $13-25$.

Bugaje, I.M. Mohammed, I.A. (2008). Biofuels Production for Transport Sector in Nigeria. Int. J. Dev. Studies 3: 36-39.

Chia, A.M. Lombardi, A.T. Grac, M.D. Melão, G. Parrish, C.C. (2013a). Effects of Cadmium and nitrogen on lipid composition of Chlorella vulgaris. Euro J. Phycology 48(1): 1-11.

Chia, A.M. Lombardi, A.T. Grac, M.D. Melão, G. Parrish, C.C. (2013b). Lipid composition of Chlorella vulgaris as a function of different Cadmium and phosphate concentrations. Aquatic Toxicology 128: 171-182.

Chen, C. Yeh, K. Aisyah, A. Lee, D. Chang, J. (2011). Cultivation, photobioreactor design and harvesting of microalgae for biodiesel production: A critical review. Bioresour. Technol. 102: 71-81.
Cheng, L. Zhang, L. Chen, H. Gao, C. (2006). Carbon dioxide removal from air by microalgae cultured in a membrane-photobioreactor. Sep. Pur. Technol. 50: 324-329.

Chidiezie, T.C. Benjamin, E. Okechukwu, N. (2005). Relation between global radiation and food production in a humid tropical climate of West Africa. J. Cent. Eur. Agric. 6: 179-184.

Chisti, Y. (2007). Biodiesel from microalgae. Biotechnol. Adv. 25: 294-306.

Chiu, S.Y. Kao, C.Y. Tsai, M.T. Ong, S.C. Chen, C.H. Lin, C.S. (2009). Lipid accumulation and $\mathrm{CO}_{2}$ utilization of Nannochloropsis oculata in response to $\mathrm{CO}_{2}$ aeration. Bioresour. Technol.100: 833-838.

Curtis, P.J. Megard, R.O. (1987). Interactions among irradiance, oxygen evolution and nitrite uptake by Chlamydomonas (Chlorophyceae). J. Phycol. 23: 608-613.

de Boer, K. Moheimani, N.R. Borowitzka M.A. Bahri, P.A. (2012). Extraction and conversion pathways for microalgae to biodiesel: a review focused on energy consumption. J. Appl. Phycol. 24: 1681-1698.

Fábregas, J. Maseda, A. Domínguez, A. Otero, A. (2004). The cell composition of Nannochloropsis sp. changes under different irradiances in semicontinuous culture. W. J. Microbiol Biotechnol. 20: 31-35.

Feng, D. Chen, Z Xue, S. Zhang, W. (2011). Increased lipid production of the marine oleaginous microalgae Isochrysis zhangjiangensis (Chrysophyta) by nitrogen supplement. Bioresour. Technol. 102: 67106716.

Galadima, A. Garba, ZN. Ibrahim, B.M. Almustapha, M.N. Leke, L. Adam, I.K. (2011). Biofuels Production in Nigeria: The Policy and Public Opinions Journal of Sustainable Development 4: 22-31.

González-López, C.V. Acién, F.G. FernándezSevilla, J.M. Sánchez-Fernández, J.F. Cerón, M.C. Molina, E. (2009). Utilization of the cyanobacteria Anabaena sp. ATCC 33047 in $\mathrm{CO}_{2}$ removal processes. Bioresour. Technol.100: 5904-5910. 
Habib, M.A.B. Parvin, M. Huntington, T.C. Hassan, M.R. (2008). A review on culture, production and use of Spirulina as food for humans and feed for domestic animals and fish. FAO Fisheries and Aquaculture Circular. No. 1034. Rome, FAO. 2008. 33p.

Herzog, H. Eliasson, B. Kaarstad, O. (2000) Capturing greenhouse gases. Sci. Am. 282: 7279.

Highina, B.K. Bugaje, I.M. Umar, B. (2011). Liquid Biofuels as alternative transport Fuels in Nigeria. J. Appl. Technol. Environmental Sanitation 1: 317-327.

Hsueh, H.T. Li, W.J. Chen, H.H. Chu, H. (2009). Carbon bio-fixation by photosynthesis of Thermosynechococcus sp. CL-1 and Nannochloropsis oculata. J Photochem Photobiol B: Biol. 95: 33-39.

Hu, H.H. Gao, K.S. (2003). Optimization of growth and fatty acid composition of a unicellular marine picoplankton Nannochloropsis sp. with enriched carbon sources. Biotechnol. Lett. 25: 421-425.

Hu, Q. Sommerfield, M. Jarvis, E. Ghirardi, M. Posewitz, M. Seibert, M. Darzins, A. (2008). Microalgal triacylglycerols as feedstocks for biofuel production: perspectives and advances. The Plant J. 54: 621-639.

Idusuyi, N. Ajide, O.O. Abu, R. (2012). Biodiesel as an Alternative Energy Resource in Southwest Nigeria. Int. J. Sci. Technol. 2: 323327.

Jegede, A.O. (2012). Anaerobic digestion of cyanobacteria and chlorella to produce methane for biofuel Int. J. Agric. and Biol. Eng. 5: 1-8.

Jorquera, O. Kiperstok, A. Sales, E.A. Embiruçu, M. Ghirardi, M.L. (2010). Comparative energy life-cycle analyses of microalgal biomass production in open ponds and photobioreactors. Bioresour. Technol. 101: 1406-1413.

Kadiri, M.O. (1999). Phytoplankton distribution in some coastal waters of Nigeria. Nig. J. Bot. 12: 51-62.

Khan, S.A. Hussain, R.M.Z Prasad, S. Banerjee, U.C. (2009). Prospects of biodiesel production from microalgae in India. Renew. Sustain. Energy Rev. 13: 2361-2372.

Klyachko-Gurvich, G.L. Tsoglin, L.N. Doucha, J. Kopetskii, J. Shebalina, I.B. Semenenko, V.E. (1999). Desaturation of fatty acids as an adaptive response to shifts in light intensity. Physiologia Plantarum 107: 240-249.

Knoshaug E.P. Darzins, A. (2011). Algal biofuel: the process. Chem. Eng. Progress 107: 37-47.

Laws, E. A., Taguchi, S., Hirata, J., and Pang, L. (1986). High algal production rates achieved in a shallow outdoor fume. Biotechnol. Bioeng. 28: 191 - 197.

Li, X. Hu, H.Y. Gan, K. Sun, Y.X. (2010). Effects of different nitrogen and phosphorus concentrations on the growth, nutrient uptake, and lipid accumulation of a freshwater microalga Scenedesmus sp. Bioresour. Technol. 101: 5494-5500.

Li, Y. Horsman, M. Wu, N. Lan, C.Q. DuboisCalero, N. (2008). Biofuels from microalgae. Biotechnol. Program 24: 815-820.

Li, Z Yuan, H. Yang, J. Li, B. (2011). Optimization of the biomass production of oil algae Chlorella minutissima UTEX2341. Bioresour. Technol. 102: 9128-9134.

Liu, A. Chen, W. Zheng, L. Song, L. (2011). Identification of high-lipid producers for biodiesel production from forty-three green algal isolates in China. Progress in Natural Science: Materials International 21: 269-276.

Luo, H.P. Al-Dahlan, M.H. (2004). Analyzing and modeling of photobioreactors by combining first principles of physiology and hydrodynamics. Biotechnol Bioeng. 85: 382393.

Mata, T.M. Martins, A.A. Caetano, N.S. (2010). Microalgae for biodiesel production and other applications: A review. Renew. Sustain. Energy Rev. 14: 217-232.

Meseck, S.L. Alix, J.H. Wikfors, G.H. (2005). Photoperiod and light intensity effects on growth and utilization of nutrients by the aquaculture feed microalga, Tetraselmis chui (PLY429). Aquaculture 246: 393-404. 
Moheimani, N.R. (2013). I norganic carbon and $\mathrm{pH}$ effect on growth and lipid productivity of Tetraselmis suecica and Chlorella sp (Chlorophyta) grown outdoors in bag photobioreactors. J. Appl. Phycol. 25: 387-398.

Moheimani, N.R. Webb, J.P. Borowitzka, M.A. (2012). Bioremediation and other potential applications of coccolithophorid algae: A review. Algal Research 1: 120-133.

Nwankwo, D.I. (1996). Phytoplankton diversity and succession in Lagos Lagoon, Nigeria. Hydrobiol. 135: 529 - 85.

Ogbonda, K.H. Amingo, R.E. Abu, G.O. (2007). Influence of aeration and lighting on biomass production and protein biosynthesis in a Spirulina sp. isolated from an oil-polluted brakish water marsh in the Niger Delta, Nigeria. Afri. J. Biotechnol. 6: 2596-2600.

Ogbonna, I. O. (2014), Biodiesel production potentials of microalgae isolated from arid environments of Nigeria. PhD Thesis in the Department of Microbiology. University of Nigeria, Nsukka, Nigeria

Ogbonna, I.O, Ogbonna, J. C. (2015). I solation of microalgae species from arid environments and evaluation of their potentials for biodiesel production. Afri. J. of Biotechnol. 14(8): 15961604.

Ogbonna, J.C. Tanaka, H. (1996). Night biomass loss and changes in biochemical composition of cellc during light/dark cyclic culture of Chlorella pyrenoidosa. J. Ferm. Bioeng. 82: 558-564.

Ogbonna, J.C. Yada, H. Masui, H. Tanaka, H. (1996). A novel internally illuminated stirred tank photobioreactor for large-scale cultivation of photosynthetic cells. J. Ferment. Bioeng. 82(1): 61-67.

Ogbonna, J. C., and Moheimani, N. R. Potentials of exploiting heterotrophic metabolism for biodiesel oil production by microalgae. In Moheimani, N. R., McHenry, M. P., Boe, K., and Bahri, P. A (Eds) Biomass and biofuels from microalgae. Advances in Engineering and Biology. Springer International Publishing, ISBN: 978-3-319-16640-7. Pp 45-61 (2015)
Oghifo, O.T. (2011). “Gas Flaring/Power plants in Nigeria: Socio-economic and Environmental Impact on the People of Niger Delta" BE306E Master's Thesis in Environmental Management. Universitetet Nordland Bodø Graduate School of Business (Bodø, Norway).

Okolocha C.F. (2010). Socio-economic implications of renewable energy in climate change adaptation. $1^{\text {st }}$ International Conference for Energy and Climate Change (ICECC, 2010).

Oniemola P.K. Sanusi G. (2009). The Nigerian Bio-fuel Policy and Incentives (2007): A Need to Follow the Brazilian Pathway International Association for Energy Economics. Fourth Quarter 2009, 35-39.

Oniya, O. O. Bamgboye, A. I. (2012). Loofah (Luffa cylindrica, I.) Biodiesel as fuel for diesel engine. J. Eng. Appl. Sci. 4: 8-18.

OPEC Oil Reserve Data (2012). Annual Statistical Bulletin 2014. http://www. opec.org/opec web/en/data graph s/330.htm).

Opute, F.I. (1991). A checklist of the freshwater brakish and marine phytoplankton of Warri/Forcadoes estuaries of southern Nigeria. Nig. J. Bot. 4: 227-254.

Oshewolo S. (2012). Designed to Fail? Nigeria's Quest for Biofuel. Afro Asian J. Soc. Sci. 3: 113.

Pimentel, D. Patzek, T.W. (2005). "Ethanol Production Using Corn, Switch grass, and Wood; Biodiesel Production Using Soybean and Sunflower." Journal of Natural Resources Research 4: 65-76.

Rittmann, B.E. (2008). Opportunity for renewable bio-energy using microorganisms. Biotechnol. Bioeng. 100: 203-212.

Samuel, O.D. Adekomaya, S.O. (2012). Challenges Confronting Sustainability of Biodiesel in Nigeria. Energy and Environmental Eng. J. 1: 41-44.

Schenk, P.M. Thomas-Hall, S.R. Stephens, E. Marx, U.C. Mussgnug, J.H. Posten, C. Kruse, O. Hankamer, B. (2008). Second generation biofuels: High-efficiency microalgae for biodiesel production. Bioenerg. Res. 1: 20-43. 
Scott, S.A. Davey, M.P. Dennis, J.S. Horst, I. Howe, C.J . Lea-Smith, D.J. Smith A. G. (2010). Biodiesel from algae: challenges and prospects. Curr. Opin. Biotechnol. 21: 277-286.

Sicko-Goad, L. Andresen, N.A. (1991). Effect of growth and light/ dark cycles on diatom lipid content and composition. J. Phycol. 27: 710718.

Sielhorst, S. Molenaar, J.W. Offermans, D. (2008). Biofuels in Africa: An assessment of risks and benefits for African wetlands (2008) Wetland International. www.wetlands.org

Sing, M.S.D.F. (2010). Strain selection and outdoor cultivation of halophilic microalgae with potential for large-scale biodiesel production. Doctor of philosophy of Murdoch University, Australia.

Sing, S.F. Borowitzka, M.A. Moheimani, N.R. (2013). Production of biofuels from microalgae. Mitigation and Adaptation Strategies for Global Change 18: 47-72.

Song, D. Fu, J. Shi, D. (2008). Exploitation of oil-bearing microalgae for biodiesel. Chinese J. Biotechnol. 24: 341-348.

Terry, K.L. Hirata, J. Laws, E.A. (1983). Lightlimited growth of two strains of the marine diatom Phaeodactylum tricornutum Bohlin: chemical composition, carbon partitioning and the diel periodicity of physiological processes. J. Experimental Marine and Biol. Ecology 68: 209-227.

Terry, K. L., and Raymond, L. P. (1985). System design for the autotrophic production of microalgae. Enzym. Microb. Technol. 7: 474 - 487.
Thompson, P. (1999). The response of growth and biochemical composition to variations in daylength, temperature, and irradiance in the marine diatom Thalassiosira pseudonana (Bacillariophyceae). J. Phycol. 35:1215-1223.

Thompson, P.A. Harrison, P.J. Whyte, J.N.C. (1990). Influence of irradiance on the fatty acid composition of phytoplankton. J. Phycol. 26: 278-288.

Ugwu, C.U. Ogbonna, J.C. Tanaka, H. (2005). Light/dark cyclic movement of algal culture (Synechocytis aquatilis) in outdoor inclined photobioreactor equipped with static mixers for efficient production of biomass. Biotech. Lett. 27: 75-78.

Veziroglu, T.N. (2008). Sumer, S. 21st Century's energy: Hydrogen energy system. Energy Conversion and Management 49: 18201831.

Vonshak, A. (1990). Recent advances in microalgal biotechnology. Biotech. Adv. 8: 70927.

Yeh, K.L. Chang J . (2012). Effects of cultivation conditions and media composition on cell growth and lipid productivity of indigenous microalga Chlorella vulgaris ESP-31. Bioresour. Technol. 105: 120-127.

Zhang, X.Z. Hu, Q. Sommerfeld, M. Puruhito, E. Chen, Y.S. (2010). Harvesting algal biomass for biofuels using ultrafiltration membranes. Bioresour. Technol. 101: 5279-5304. 